Tech Otherwise • CSCW '20

\title{
We Will Not Be Pacified Through Participation
}

\section{Alex Ahmed}

Published on: Oct 15, 2020

DOI: $10.21428 / 93 b 2 c 832 . e 4 a a 9 a 47$

License: Creative Commons Attribution 4.0 International License (CC-BY 4.0). 


\title{
We Will Not Be Pacified Through Participation
}

\author{
By Alex A Ahmed \\ Human Computer Interaction Institute, Carnegie Mellon University \\ alexahme@andrew.cmu.edu
}

\begin{abstract}
Much ink has been spilled extolling the virtues of participatory and human-centered design. Recent work has proposed that "participatory AI" could rehabilitate AI's image such that it "can be seen as an ethical and trustworthy city asset rather than an adversary fraught with controversy and bias" [1]. The ideological position of this work is clear, though never stated directly. It assumes that technological change is inevitable [2], fetishizes an abstract "diversity of opinions" and seeks a peaceful continuation of the status quo over disruptive "controversy." This framing obscures the actual decision-makers at play - corporate tech executives and state officials - and casts activists and organizers as troublemakers who might be pacified through participation. This position paper argues that "participation" is a racist, pro-capitalist, anti-worker strategy that should be rejected in all its forms. Instead, we should support and actively build working-class power inside and outside tech and academia.
\end{abstract}

The ruse of participation goes back at least a century in the United States. Labor historian Toni Gilpin describes how, in the midst of the Great Depression, the wealthiest and most powerful corporate executives of their time - working together under the Special Conference Committee (SCC) in 1919 devised a plan to appease workers while quietly undermining their unions.

While bosses might no longer call the police to murder striking workers in the street, they would create a "works council" for capital and labor to "work out their problems" [3]. For example, under this system, workers in a factory would choose representatives to speak on their behalf, who would join with management representatives in equal numbers to collaborate on problems facing the workplace. But this corporate benevolence, perhaps unsurprisingly, did not lead to improved conditions for workers. The councils would tie on votes concerning raises for workers (with management opposed and workers in favor, of course); however, ties would be broken by the company president. Gilpin connects this management strategy to a broader effort by corporations to repair their reputations while securing their power and profits, all of which were damaged by decades of fervent labor unrest. This strategy succeeded, congealing into the Human Resources departments, diversity and inclusion committees, Faculty Senates, and "listening sessions" that we experience in our workplaces today. 
This is why we must be skeptical of any institutionally-controlled body that claims to "work out problems." Jason England and Richard Purcell condemned universities' "toothless" responses to antiBlack police brutality and the murder of George Floyd, writing that "what tends to follow hollow official statements is a cliché slate of programming: focus groups, town halls, anti-racism reading lists, testimonials of hurt, confessions of guilt that accommodate "both sides"' [4]. This "both sides"-ism assumes that conversation and participation (rather than material shifts in power and resources) will be enough to combat and overturn centuries of racial oppression. Sara Ahmed has thoroughly explained how "diversity work" can be a way for the university to avoid the work while maintaining a progressive public image, while trapping and extracting labor and energy from marginalized people [5].

Muneeza Rizvi and Paula Thompson take up this issue in the context of "Countering Violent Extremism" (CVE) programs in the US and the UK [6]. Barack Obama's CVE program, first launched in 2011, is fundamentally racist and Islamophobic [7]. It primarily targets Muslims, who are assumed to be or to eventually become terrorists. However, it has been recently rebranded in terms of "community participation," "public health," and "community wellness"; this "soft power" approach recruits Muslims themselves further their own stigmatization and surveillance, alongside health and education professionals. Rizvi and Thompson argue that CVE is just one example of a larger agenda of "community policing" in the US:

At a quick glance, these "community-oriented" or "participatory" styles of policing appear to break from existing paradigms of surveillance and punishment.... But such approaches simply delegate policing duties across new networks, ultimately expanding the reach of a widely criticised criminal justice system. Further, the common rhetoric of "collaboration" and "cooperation" surrounding such efforts obscures the deeply conditional character of "partnerships" with the state. [6]

Just as corporations in the 1920s rebranded anti-unionism and worker repression as empowerment and participation through "works councils," law enforcement agencies are doing the same with surveillance and racism through "community policing." It's only natural, then, that AI and predictive policing algorithms are now being peddled through community-oriented initiatives to rehabilitate their image [1]. Such efforts are indeed "conditional" in that we must accept their foundational premise: participation is invited from certain groups, but it is not binding, and power and authority should never, ever be challenged.

But if this doesn't work, what does? History shows us not only how we got here, but also how people have fought back. "Participation" and "collaboration" are vacuous concepts; the greatest gains - from the eight hour day onward - were achieved through struggle and direct confrontation with the halls of power. Whether you are at a university that is pursuing contracts to create autonomous killing 
machines for the US military [8], a tech company that is rolling out racist "predictive policing" algorithms [9], or any workplace that should be treating you or your community better, we must create and join organizations outside of and against corporate/institutional actors. Anything else is destined to be a pointless PR exercise.

\section{References}

1. Falco, Gregory (2019). Participatory AI: Reducing AI Bias and Developing Socially Responsible AI in Smart Cities - IEEE Conference on Computational Science and Engineering, CSE.

2. Johnson, Adam \& Shirazi, Nima (2019). Citations Needed Episode 92: The Responsibility-ErasingCatch-all of 'Automation'.

3. Gilpin, Toni (2020). The Long Deep Grudge: A Story of Big Capital, Radical Labor, and Class War in the American Heartland. Haymarket Books.

4. Jason England and Richard Purcell (2020). Higher Ed's Toothless Response to the Killing of George Floyd. The Chronicle of Higher Education.

5. Ahmed, Sara (2012). On being included: racism and diversity in institutional life. Duke University Press.

6. Rizvi, Muneeza \& Thompson, Paula (2020). Community policing already exists in the US and it is dangerous. Al-Jazeera.

7. Muslim Justice League. What is "Countering Violent Extremism" (CVE)? https://www.muslimjusticeleague.org/cve/

8. CMU Against ICE (2020). Disorientation Guide. https://www.cmuagainstice.com/dis-orientationguide

9. Coalition Against Predictive Policing In Pittsburgh. https://capp-pgh.com/ 